\title{
The Cosmic Cycles of Kimberlite Volkanism: New Data
}

Mal'kov, B.A.

Institute of Geology, Komi Science Centre of the Ural division, Russian Acad Sci., Syktyvkar, 167610, Russia

Earlier has been shown a cosmic periodicity of kimberlite volcanism (Mal'kov, 1994). Its synphase episodes form homological rows with the time step of $215 \mathrm{Ma}$. There are 16 such rows in Phanerozoic, including 3 last cosmic cycles of tectogenesis (CTC). The completeness of the homological rows is different. Also there are vacancies in them. On the sinusoid expressing harmonic character of oscillation of the Earth-Moon system the homological rows are distributed simmetrically. At "humps" of the sinusoid they form concentrations. Major epochs of the kimberlite volcanism, including, as a rule, episodes of 2-3 homological rows closed in time are drown towards the "humps" of the sinusoid.

The Paleozoic kimberlites of the Russian, Siberian and Australian platforms of 400-340 Ma age belong to homological rows 10-14 that are situated symmetrically in the apical part of the "hump" of the sinusoid around 375 Ma maximum located in row 12 . The Jurassic kimberlites of the Siberian, Canadian, African and Australian platforms of 189-135 Ma age belong to more young volcanic episodes of the same five homological rows $10-14$, but they are symmetric to the 160 Ma maximum located in row 12. The Late Cretaceous and Paleogene kimberlites of the African, Brazilian, Canadian and North-Chinese platforms and Australian Miocene lamproites of the 95-20 Ma age belong to 6 homological rows 2-7 situated symmetrically in apical part of "hump" of the sinusoid around 52 Ma maximum located in row 4 .

The homological rows 8 and 16 correspond the neutral position of the Earth-Moon system at the Moon altitude equal 60 Earth radiuses. Critical moments of row 8 are mostly vacant (107, 322 and $537 \mathrm{Ma}$ ), exept of the latter. The Venetia kimberlites of 530-540 Ma age in the Limpopo mobile belt and the Chuanxian lamproites of the same age in Yangtze craton correspond to it. The episodes of volcanism corresponding to the critical moments of row $16(213,428,643 \mathrm{Ma})$ are not found, exept of the former. The Pozdnyaya pipe in the Middle Olenek district being of $217 \mathrm{Ma}$ age could be assign to the row.

The homological rows of episodes of kimberlite volcanism display a stability during 8 last CTC up to the limit of $1720 \mathrm{Ma}$. The amount of the vacancies in these rows and cycles (CTC) retrospectively grows. In the Late Proterozoic many homological rows "disapeared", because of imperfection of geological records. At present, precisely dated episodes of kimberlite volcanism are established only for 7 from the 16 known homological rows. They are rows $1,2,4,7,8,14,15$.

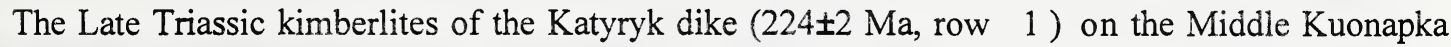
belonging to the CTC 2 have their predecessors in CTC 3, 6: the "325 years of Yakutia" pipe kimberlites (440.2 Ma; CTC 3) in the Upper Muna field of Yakutia and the Wajrakarur kimberlites (1091 $20 \mathrm{Ma}$; CTC 6) i n Central India (Table 1).

The Australian Miocene lamproites (20 Ma; row 2) have their predecessors in CTC 2, 3, 5: the Jwaneng pipe kimberlites in southern Botswana (235 $\pm 2 \mathrm{Ma}$; CTC 2), the Arctic pipe kimberlites in the Middle Kuonapka (235 $44 \mathrm{Ma}$; CTC 2), the Amakinskaya pipe kimberlites in the MaloBotuobinski district (449.8 Ma; CTC 3) and the Quebec kimberlites (1100 Ma; CTC 5). 
The Paleogene kimberlites (52 Ma; row 4) known in the Slave craton (Canada), Tanzania, Namaqualand and China have their Proterozoic predecessors in CTC 4, 6, 7. Those are the Tieling kimberlites in the North China platform (701 Ma; CTC 4), the Argyle lamproites (1130 $\mathrm{Ma}$; CTC 6) in Australia and the South India kimberlites (1350 Ma; CTC 7) (T able 2).

The Late Cretaceous kimberlites of the Kimberley (95.4 Ma; row 7 ) have their predecessors in CTC 6, 7, 8: the Premier pipe kimberlites (1180 Ma; CTC 6), the Cote d'Ivoire kimberlites (1385 Ma; CTC 7); the Kuruman kimberlites (1600 Ma; CTC 8) in RSA (Table 3).

The Early Jurassic kimberlites of the Mwadui pipe (189 Ma; row 14) in Tanzania have their predecessors in CTC 2, 6: the Tayegznaya pipe kimberlites (403 Ma; CTC 2) in Yakutia and the Umbinskaya pipe kimberlites (400 Ma; CTC 2) in the Timan Ridge and kimberlites of PreSayany (1268 Ma; CTC 6). The Early Jurassic kimberlites of the Dokolwayo pipe in Swaziland (200 Ma; row 15) have their predecessor in CTC 2, 5: the Drugzba pipe (411.5 Ma; CTC 5) in Yakutia and the Mejhgawan pipe (1067 $\pm 31 \mathrm{Ma}$; CTC 5 ) in North India (Table 4).

Synphase and global character of the kimberlite volcanism episodes during all or many cycles of tectogenesis convince us in its cosmic causes. All episodes of the kimberlite volcanism are predetermined. Hence we can predict the absolute age and CTC phase of the vacancies in the incomplete homological rows.

\section{References}

Chatterjee, B., Smith, Ch. B., Jha, N., and Khan, M.W.Y., 1995, Kimberlites of Southeastern Raipur kimberlitic field, Raipur District, Madhya Pradesh, Central India: Extended Abstr. Sixth Intern. Kimberl. Conf., Novosibirsk, p. 106-108.

Davis, G.L., Sobolev, N.V., and Khar'kiv, A.D., 1980, New data on the age of Yakutian kimberlites obtained by the uranium-lead method on zircons: Doklady Akad Nauk SSSR, 254, 1, p. 175-179. Gurney, J.L., and Gurney, J.J., 1995. Garnet and ilmenite from some Premier kimberlite intrusives: Extended Abstr. Sixth Intern. Kimberl. Conf., Novosibirsk, p. 211-212.

Kinny, P.D., Griffin, B.J., Heaman, L.M., Brakhfogel, F.F., and Spetsius, Z.V., 1997, SHRIMP U$\mathrm{Pb}$ ages of perovskite from Yakutian kimberlites: Russian Geology and Geophysics, V.38, 1, p.91-99.

Kopylova, M.G., Gurney, J.J., and Daniels, L.R.M., 1995, Mineral inclusions in diamonds from the River Ranch kimberlite: Extended Abstr. Sixth Intern. Kimberl. Conf., Novosibirsk, p. 289-291.

Lu, F., Zheng, J., Zhao, L., Xia, W., and Zhang, H., 1995, Paleozoic lithospheric mantle composition and processes beneath North China Platform: Extended Abstr. Sixth Intern. Kimberl. Conf., Novosibirsk, p. 336-338

Mal'kov, B.A., 1994, Cosmic cycles of kimberlite volcanism: Doklady Akad Nauk SSSR, 338, 6, p.798-801 (in Russian)

Mal'kov, B.A., 1997, Geology and petrology of kimberlites: Nauka, St-Petersburg, 282 pp. (in Russian)

Pell, J.A., 1997, Kimberlites in the Slave Craton, Northwest Territories, Canada: a prelimenery rewiev: Russian Geology and Geophysics, V.38, 1, p. 9-18. 
Table 1. The homological row ( 1 ) of kimberlites (203:215)

\begin{tabular}{c|l|c|c}
\hline $\begin{array}{c}\text { Absolute age } \\
M a\end{array}$ & \multicolumn{1}{|c}{ Synphase kimberlites } & Phase of CTC & CTC \\
\hline$(10)$ & Vacancy 215 & \\
$224 \pm 2^{\mathbf{x}}$ & Katyryk dike, Yakutia & $203: 215$ & 1 \\
$440,2^{\mathbf{x}}$ & "325 years of Yakutia" pipe, Yakutia & $204: 215$ & 2 \\
$(655)$ & Vacancy & $203: 215$ & 3 \\
$(870)$ & Vacancy & $203: 215$ & 4 \\
$1091 \pm 20^{*}$ & Wajrakarur pipe, Andhra Pradesh, India & $203: 215$ & 5 \\
& & $199: 215$ & 6
\end{tabular}

Note: ${ }^{x}$ - dated by the U-Pb method on perovskite (Kinny et al., 1997); ${ }^{\mathrm{xx}}$ - dated by the U-Pb method on zircon (Davis et al., 1980); * dated by Rb-Sr method (Chatterjee et al., 1995).

Table 2. The homological row ( 4 ) of kimberlites and lamproites (160:215)

\begin{tabular}{|c|c|c|c|}
\hline $\begin{array}{c}\text { Absolute age } \\
M a\end{array}$ & Synphase kimberlites and lamproites & $\begin{array}{c}\text { Phase of CTC } \\
t: 215\end{array}$ & $\overline{C T C}$ \\
\hline $52^{x}$ & $\begin{array}{l}\text { Kimberlites in the Slave Craton, Canada } \\
\text { Kimberlites of the Nzega field, Tanzania } \\
\text { Kimberlites of the Brackfontein, RSA }\end{array}$ & $160: 215$ & 1 \\
\hline $701^{x x}$ & Tieling kimberlites in the Ji-Lu-Liao nucleus, North China & 159: 215 & 4 \\
\hline 1130 & Argyle lamproites in the Kimberley Craton & 160: 215 & 6 \\
\hline 1350 & Kimberlites of South India & $155: 215$ & 7 \\
\hline
\end{tabular}

Note: ${ }^{x}$ - dated by Rb-Sr isotopic method (Pell, 1997); ${ }^{\mathrm{xx}}$ - after Lu et al., 1995.

Table 3. The homological row ( 7 ) of kimberlites (120:215)

\begin{tabular}{c|l|c|c}
\hline $\begin{array}{c}\text { Absolute age } \\
\text { Ma }\end{array}$ & \multicolumn{1}{|c|}{ Synphase kimberlites } & $\begin{array}{c}\text { Phase of CTC } \\
t: 215\end{array}$ & CTC \\
\hline 95.4 & Kimberley pipe, RSA & $120: 215$ & 1 \\
$530-540^{\mathrm{x}}$ & Venetia cluster of kimberlite pipes, RSA & $109: 215$ & 3 \\
$1180 \pm 30^{\mathrm{xx}}$ & Premier pipe, RSA & $110: 215$ & 6 \\
1385 & Kimberlites of Cote d'Ivoire & $120: 215$ & 7 \\
1600 & Kuruman cluster of kimberlite pipes, RSA & $120: 215$ & 8
\end{tabular}

Note: ${ }^{\mathbf{x}}$ - after Kopylova et al., $1995 ;^{\mathbf{x x}}$ - after Gurney and Gurney, 1995; all other dates after Mal'kov, 1994.

Table 4. The homological row ( 15$)$ of kimberlites (13:215)

\begin{tabular}{c|l|c|c}
\hline $\begin{array}{c}\text { Absolute age } \\
M a\end{array}$ & \multicolumn{1}{|c}{ Synphase kimberlites } & Phase of CTC & CTC \\
\hline 200 & Dokolwayo pipe, Swaziland 215 & \\
411.5 & Drugzba pipe, Yakutia & $13: 215$ & 1 \\
$(630)$ & Vacancy & $18: 215$ & 2 \\
$(845)$ & Vacancy & $13: 215$ & 3 \\
$1067 \pm 31^{\mathrm{x}}$ & Mejhgawan pipe, Madhya Pradesh, India & $13: 215$ & 4 \\
$1268 \pm 12$ & Kimberlites of Pre-Sayany area, Russia & $8: 215$ & 5 \\
$(1490)$ & Vacancy & $22: 215$ & 6 \\
& & $13: 215$ & 7 \\
\hline
\end{tabular}

Note: ${ }^{x}$ - after Chatterjee et al., 1995; all other dates after Mal'kov $(1994,1997)$ 